\title{
$\mathrm{KNiFe}(\mathrm{CN})_{6}$ 전기화학적 이온교환체를 이용한 세슘 양이온의 분리에 관한 연구
}

\author{
황영기* \\ 경남대학교 전기공학과
}

(2012년 10월 17일 접수 : 2012년 11월 25일 채택)

\section{A Study on the Separation of Cesium Cations by Using Electrochemical Ion Exchanger of $\mathrm{KNiFe}(\mathrm{CN})_{6}$}

\author{
Young Gi Hwang* \\ Department of Electrical Engineering, Kyungnam University, Changwon 631-701, Korea
}

(Received October 17, 2012 : Accepted November 25, 2012)

초 록

본 연구에서는 전기화학적 이온교환체 중의 하나인 nickel hexacyanoferrate $\left(\mathrm{KNiFe}(\mathrm{CN})_{6}\right)$ 막 전극을 사용하여 세슘 양이온을 분리하는 실험을 수행하였다. $1.0 \mathrm{M} \mathrm{NaNO}$ 와 $1.0 \mathrm{M} \mathrm{CsNO}$ 의 단일성분계 및 이성분계 수용액에서 순환전위곡선을 측정하여 전극전위, 전류, 전기량의 변화 거 동을 조사하였으며, 실험 전과 후에 $\mathrm{KNiFe}(\mathrm{CN})_{6}$ 막의 구조 형태와 원자조성의 변화를 각각 $\mathrm{SEM}$ 과 EDS 분석을 통하여 조사하였다. 또한 나트륨과 세슘 용액에서 교대로 이온교환 반응을 수행하여 측정한 순환전위곡선과 원자조성으로부터 $\mathrm{KNiFe}(\mathrm{CN})_{6}$ 의 이온 선택성을 조사하였다. 본 연구의 실험 결과에 의하면, 전기를 인가한 $\mathrm{KNiFe}(\mathrm{CN})_{6}$ 이온교환체는 화학적 유·무기물 이온교 환체에 비해 약 40 배 이상의 우수한 내구성을 가짐을 알 수 있었다. 또한 $\mathrm{KNiFe}(\mathrm{CN})_{6}$ 이온교 환체는 나트륨보다 세슘에 대해 보다 높은 선택도를 가짐을 확인할 수 있었다.

\begin{abstract}
This study was performed to investigate the separation of cesium cations by using an electrochemical ion exchanger of nickel hexacyanoferrate $\left(\mathrm{KNiFe}(\mathrm{CN})_{6}\right)$ film electrode. Potential, current, and charge passing through the cyclic voltammograms were measured in singular and binary solutions of $1.0 \mathrm{M} \mathrm{NaNO}_{3}$ and $1.0 \mathrm{M} \mathrm{CsNO}_{3}$. Before and after each experiment, the structural morphology and atomic composition of $\mathrm{KNiFe}(\mathrm{CN})_{6}$ were analyzed by SEM and EDS, respectively. The ion selectivity of $\mathrm{KNiFe}(\mathrm{CN})_{6}$ was also observed by the voltammograms and atomic compositions measured in the solution alternated between sodium and cesium. As the result of this study, it was found that the electrically switched $\mathrm{KNiFe}(\mathrm{CN})_{6}$ ion exchanger had the significant advantage of 40 times or longer durability than conventional organic or inorganic ion exchanger. It was also shown that the $\mathrm{KNiFe}(\mathrm{CN})_{6}$ ion exchanger had high selectivity for cesium over sodium.
\end{abstract}

Keywords : Nickel hexacyanoferrate $\left(\mathrm{KNiFe}(\mathrm{CN})_{6}\right)$, Electrochemical ion exchanger, Separation of cesium cations, Radioactive elements, Ion selectivity

*E-mail: yghwang@kyungnam.ac.kr 


\section{1. 서}

각종 산업폐수로부터 중금속이나 방사성 양이온을 효과적으로 그리고 경제적으로 분리하거나 제거하는 기술은 오늘날 매우 중요한 과제로 부상하고 있다. 폐 수로부터 중금속 양이온을 회수하고 공업용수로 재활 용하는 과제와 우리나라와 같이 원자력 의존도가 높 은 국가에서 방사성 양이온을 분리하여 농축함으로써 액상폐기물의 저장부피를 감축하는 과제는 반드시 해 결해야 할 문제이다. 이러한 문제를 해결하기 위해 선 진국에서는 현재 널리 사용되고 있는 일반 이온교환 법(ion exchange)을 대체할 신기술로 이온교환법과 전 기분해법(electrolysis)을 결합시킨 전기화학적 이온교 환법(electrochemical ion exchange)에 관한 연구를 집중하고 있다. ${ }^{1-7)}$

방사성 양이온을 함유하고 있는 폐기물은 주로 원 자력 에너지 산업체로부터 발생한다. 핵분열 반응기의 냉각수 형태, 지하 저장품으로 배출되는 고준위 또는 중준위 고상 및 액상 폐기물 형태, 또는 때때로 산업 체 인근의 오염된 지하수 형태로 발생된다. 이들 중 중준위 또는 저준위 상태인 액상 폐기물은 종종 방사 성 양이온을 제거하여 낮은 농도로 처리한 후에 냉각 수로 재활용하거나 해양으로 방류한다. 현재까지 보고 된 방사성 양이온의 분리공정 중 가장 효과적이라고 평가되는 기법은 유-무기물 이온교환체를 이용하는 일반 이온교환법이다. ${ }^{8-14)}$ 이 방법은 방사성 양이온의 농도 저감은 용이하나 산추출, 교환체의 수세, 나트륨 의 첨가 등과 같은 일련의 과정을 거치므로, 2 차적인 폐수 발생량이 크다는 문제점을 가지고 있다. 또한 유 - 무기물 이온교환체를 사용하면 1회 싸이클마다 $2 \sim 3 \%$ 씩의 효능 감소가 일어나므로, ${ }^{10,11,15-17)}$ 그 수명이 30 50 싸이클에 지나지 않고 폐기되는 다량의 교환체 에 의해 2 차적인 오염이 발생한다. 이러한 단점을 해 결하기 위해 전기적 작용을 가하는 이온교환법이 최 근 들어 소개되었으며 선진국들을 중심으로 많은 연 구가 진행되고 있다.

전기화학적 이온교환법은 분자 격자 간에 빈 공간 을 가지는 전도성 이온교환체를 전도성 물체의 표면 에 도포시킨 후에 전기에너지를 가하여, 이온교환체 분자 격자간의 빈 공간에 방사성 양이온을 침적시키 는 원리에 근거하고 있다. 또한 방사성 성분이 침적된 이온교환체를 농축조로 이송하고 전기적으로 가역반 응시키면, 방사성 성분이 이온교환체로부터 해리되어 농축되게 할 수 있다. 이러한 침적-해리 과정(환원-산 화 과정)을 반복함으로써, 전도성 이온교환체를 재생 하여 재활용할 수 있고, 충분히 농축된 용액을 지하 저장품으로 대체할 수 있으므로 저장 부피를 저감시
킬 수 있다. 전기화학적 이온교환법을 산업체에 응용 하기 위해서는 이온교환체의 제조에 관한 연구가 완 성되어야 하고 적용이 가능한 운전조건을 규명하여야 하며, 최종적으로 일반 이온교환법에 비해 성능과 경 제성의 우위를 확보하여야 한다. 전기화학적 이온교환 법에 사용되는 전도성 이온교환체는 프러시안블루 (prussian blue) 계열의 nickel hexacyanoferrate $\left(\mathrm{NiHCNFe}, \mathrm{KNiFe}(\mathrm{CN})_{6}\right)$ 가 가장 널리 사용된다. $\mathrm{KNiFe}(\mathrm{CN})_{6}$ 이온교환체의 제조에 관한 연구는 상당 히 진전된 상황이며, ${ }^{18-22)}$ 최근 들어 미국, 일본, 중국, 인도 등을 중심으로 원자력 발전 산업체에서 사용하 고 있는 종전의 유·무기물 이온체를 $\mathrm{KNiFe}(\mathrm{CN})_{6}$ 이 온교환체나 이의 개량형으로 대체하여 방사성 액상 폐 기물을 처리하기 위한 연구에 집중하고 있으며, $2,7,23,24)$ 우리나라 한국원자력연구원 등도 이의 응용을 위한 연 구를 진행하고 있다.

본 연구자는 국내에서는 최초로 전도성 금속 표면 에 전기 퍼텐셜을 가하는 강제적 생성반응과 전도성 금속을 프러시안 용액에 담기어 자생 결합시키는 생 성반응으로 $\mathrm{KNiFe}(\mathrm{CN})_{6}$ 를 제조한 연구결과를 전보에 발표한 바가 있다. ${ }^{21)}$ 본 연구는 전보에 이어 세슘 양 이온 분리를 위한 이온교환체의 전기화학적 특성을 조 사하기 위해 수행되었다. 전보와 달리 나트륨과 세슘 을 시험성분으로 선정하고 단일 성분 수용액과 이성 분계 혼합물에서의 순환전위곡선을 측정하여 전극 전위, 전류, 전기량 등의 변화 양상을 고찰하였으며, 이온교환체의 성능 감소율(내구성)을 조사하고 세슘에 대한 선택적 적하분리가 가능한지를 확인하였다.

\section{2. 실험장치 및 방법}

전보에서 최적의 제조법으로 규명된 방법에 따라, ${ }^{21)}$ $\mathrm{NiHCNFe}$ 이온교환체를 $5 \mathrm{mM} \mathrm{K} \mathrm{K}_{3} \mathrm{Fe}(\mathrm{CN})_{6}$ 와 $100 \mathrm{mM}$ $\mathrm{KNO}_{3}$ 인 수용액에서 식(1)과 같이 118 시간 동안 자 생 결합시키는 비전해 화학적 방법으로 제조하였다.

$$
\mathrm{Ni}+\mathrm{K}_{3} \mathrm{Fe}(\mathrm{CN})_{6} \rightarrow \mathrm{KNiFe}^{\mathrm{III}}(\mathrm{CN})_{6}+2 \mathrm{~K}^{+}+2 \mathrm{e}^{-}
$$

이온교환체를 도포시키는 기지금속으로 전보에서는 $2 \times 2 \mathrm{~cm}$ 규격의 니켈판을 사용하였으나, 본 연구에서 는 미세한 반응 표면적에서의 거동을 조사하기 위해 직경이 $0.5 \mathrm{~mm}$ 이고 길이가 $10 \mathrm{~mm}$ 인 니켈선을 사용하 였다. 순도 $99.99 \%$ 인 백금판을 상대전극으로 설치하 였으며, 시험 용액으로 $1.0 \mathrm{M}$ 의 나트륨과 세슘 질산염 수용액을 사용하였고, 모든 경우에서 온도는 $25^{\circ} \mathrm{C}$ 로 유지하였다. 이온교환체 전극과 백금 전극에 인가하는 전위는 potentiostat/galvanostat $273 \mathrm{~A}$ 기기와 270 자동 
화 프로그램으로 조절하였으며, 인가 전위에 따른 시간, 전위, 전류, 전기량 변화는 GPIB 케이블로 연결 된 컴퓨터와 자동화 프로그램으로 측정하였다.

본 연구에서는 $\mathrm{NiHCNFe}$ 이온교환체의 성능 감소 율을 조사하여 일반 유- 무기물 이온교환체의 성능 감소율과 비교하기 위해, 이온교환체 전극전위를 $\mathrm{SCE}$ 기준전극 대비 $-100 \mathrm{mV}$ 에서 $800 \mathrm{mV}$ 까지 상승시키고 다시 $-100 \mathrm{mV}$ 로 강하시키는 산화-환원 반응을 2,000 회 이상 연속적으로 반복하는 순환전위법을 수행하여 전위순환 횟수에 따른 전기량 감소율을 조사하였다. $\mathrm{NiHCNFe}$ 의 양이온과의 산화-환원 반응은 식(2)와 같 이 나타낼 수 있다.

$\mathrm{KNiFe}^{\mathrm{III}}(\mathrm{CN})_{6}+2 \mathrm{M}^{+}+\mathrm{e}^{-} \underset{\text { oxid.elute }}{\stackrel{\text { red.load }}{\rightleftarrows}} \mathrm{M}_{2} \mathrm{NiFe}^{\mathrm{II}}(\mathrm{CN})_{6}+\mathrm{K}^{+}$

식(2)에 나타난 $\mathrm{M}^{+}$는 분리 대상인 양이온을 의미 하고, $\mathrm{KNiFe}(\mathrm{CN})_{6}$ 는 단순입방격자와 체심입방격자가 교대로 연결되어 있는 페리시안 구조를 가진다. 또한 $\mathrm{M}_{2} \mathrm{NiFe}(\mathrm{CN})_{6}$ 는 칼름 위치와 비어 있던 단순입방격자 의 중심점에 양이온 $\left(\mathrm{M}^{+}\right)$이 치환 및 침적되어 모두 체 심입방격자로 변화하는 페로시안 구조를 가진다. 페리 시안을 환원시키면 전자와 양이온을 받아들여 페로시 안으로 전환되고, 이 과정에서 저농도 용액으로부터 양이온이 분리된다. 또한 고농도 용액에서 페로시안을 산화시키면 침적된 양이온이 해리되므로 양이온을 농 축시킬 수 있다. 전기적인 작용을 가하여 산화-환원 반 응을 수행한 사례를 Fig. 1에 수록하였다. Fig. 1의 박 스는 주사속도(sweep rate)를 $45 \mathrm{mV} / \mathrm{s}$ 로 유지한 조건 에서 시간에 따른 $\mathrm{NiHCNFe}$ 의 전극전위 변화를 측정 한 그림이고, 인가한 전위에 따른 시간-전류 응답을 측

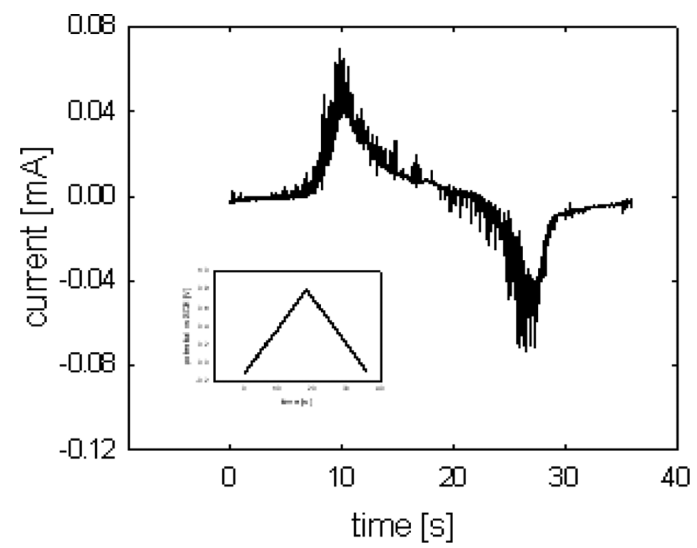

Fig. 1. Typical plot of current-time for the cyclic voltammetry.
정한 결과가 Fig. 1의 곡선이다.

$\mathrm{NiHCNFe}$ 이온교환체가 세슘과 나트륨 중 어떠한 양이온과 선택적으로 반응하는지를 조사하기 위해, 세 슘과 나트륨의 이성분계 수용액에서의 순환전위곡선 을 측정하여 단일 성분 수용액에서의 순환전위곡선 형 태와 비교하였다. 또한 나트륨 질산염 수용액에서 100 회 동안 전위순환을 반복한 후에 용액을 세슘 질산염 수용액으로 교체하고 추가적으로 20 회의 전위순환을 수행하였으며, 그 역으로도 실험을 수행하여, 순환전 위곡선의 변화거동을 살펴보았다. 용액을 교체하면서 수행한 실험이 종료된 후에 $\mathrm{NiHCNFe}$ 이온교환체 시 편의 표면 조직 형태를 $\mathrm{SEM}$ 으로 사진 촬영하고 원자 조성을 $\mathrm{EDS}$ 스펙트럼으로 분석하여, 이온 교환 전의 조직 형태 및 조성과 비교하고 이온교환체의 이온 선 택성을 정량적으로 검증해 보았다.

\section{3. 결과 및 고찰}

\section{1. $\mathrm{KNiFeCN}_{6}$ 이온교환체의 순환전위곡선 특성}

순수한 니켈과 니켈 금속 표면에 $\mathrm{NiHCNFe}$ 막을 생성시킨 전극을 각각 $1.0 \mathrm{M}$ 의 $\mathrm{NaNO}_{3}$ 와 $\mathrm{CsNO}_{3}$ 수용액에 시험전극으로 설치하고, $\mathrm{SCE}$ 기준전극 대비 $-100 \mathrm{mV}$ 에서 $800 \mathrm{mV}$ 까지 $100 \mathrm{mV} / \mathrm{s}$ 의 주사속도 로 전위변화하면서 측정한 순환전위곡선이 Fig. 2이다. $-100 \mathrm{mV}$ 에서 $800 \mathrm{mV}$ 까지 상승하는 과정에서는 산화 반응이 일어나고 $800 \mathrm{mV}$ 에서 $-100 \mathrm{mV}$ 까지 강하하 는 과정에서 환원반응이 일어나므로, 식(2)에서 기술 한 바와 같이 한 번의 전위순환은 저농도 용액에서 $\mathrm{NiHCNFe}$ 이온교환체가 양이온을 침적하고 고농도 용 액에서 양이온을 해리하는 과정에 해당한다.

Fig. 2에서 이온교환체가 입혀진 니켈로 흐른 전류

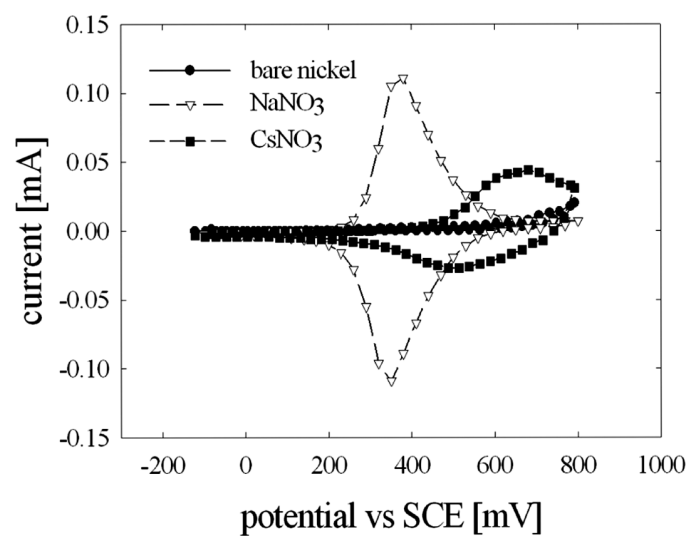

Fig. 2. Cyclic voltammograms of bare nickel and $\mathrm{NiHCNFe}$ in $1.0 \mathrm{M} \mathrm{NaNO}$ and $1.0 \mathrm{M} \mathrm{CsNO}$. 
는 순수 니켈로 흐른 전류보다 월등히 높게 측정되었 으므로, 순수 니켈보다 $\mathrm{NiHCNFe}$ 의 반응성이 우수함 을 알 수 있다. 이 실험결과로 미루어 볼 때, 순수한 니켈금속을 운전전극으로 사용하는 전기분해법은 방 사성 양이온 성분을 분리하는 자체가 불가능하거나 전 기화학적 이온교환법에 비해 극히 비효율적일 것으로 추정된다.

Fig. 3과 Fig. 4는 각각 $1.0 \mathrm{M}$ 의 $\mathrm{NaNO}_{3}$ 수용액과 $1.0 \mathrm{M} \mathrm{CsNO}$ 에서 전위순환을 3,500 회 반복하면서 측 정한 $\mathrm{NiHCNFe}$ 의 전위-전류 곡선이다. Fig. 3과 Fig. 4 의 공통점은 전위순환이 반복될수록 산화 및 환원 반 응의 피크 전류는 감소하고 피크 전류(peak current)를 갖는 산화 전위는 증가하고 환원 전위는 감소하는 경 향을 가진다는 점이다. 또한 Fig. 3과 Fig. 4의 차이 점은 양이온 성분에 따라 순환전위곡선의 형태, 피크 전류 및 대응하는 전극전위 등이 상호 상이하게 나타 난다는 점이다. 나트륨 수용액에서의 산화 및 환원 피 크 전류는 각각 $0.10 \mathrm{~mA}\left(0.64 \mathrm{~mA} / \mathrm{cm}^{2}\right)$ 와 $-0.07 \mathrm{~mA}$ 이지만 세슘 수용액에서의 피크 전류는 각각 0.045 $\mathrm{mA}\left(0.29 \mathrm{~mA} / \mathrm{cm}^{2}\right)$ 와 $-0.026 \mathrm{~mA}$ 로서 세슘보다 나트륨 에서 높게 나타났다. 또한 나트륨 질산염 수용액에서 의 산화 및 환원반응은 거의 대칭형에 가까운 형태로 서 $350 \sim 450 \mathrm{mV}$ 에서 최대 반응속도를 가지지 만 세슘의 산화 및 환원반응은 $610 \sim 710 \mathrm{mV}$ 와 470 $570 \mathrm{mV}$ 에서 각각 최대 반응속도를 가짐을 알 수 있다. 이 결과는 나트륨의 산화 및 환원반응이 동시에 350 $450 \mathrm{mV}$ 의 전극전위에서 짧은 시간에 집중적으로 진 행되지만, 세슘의 산화 및 환원반응은 각각 넓은 전극 전위 영역에서 시간에 따라 서서히 진행된다는 의미 를 내포하고 있다. 이러한 특성과 측정 자료를 이용 하면, 분리하고자 하는 성분에 따라 인가하여야 할 전

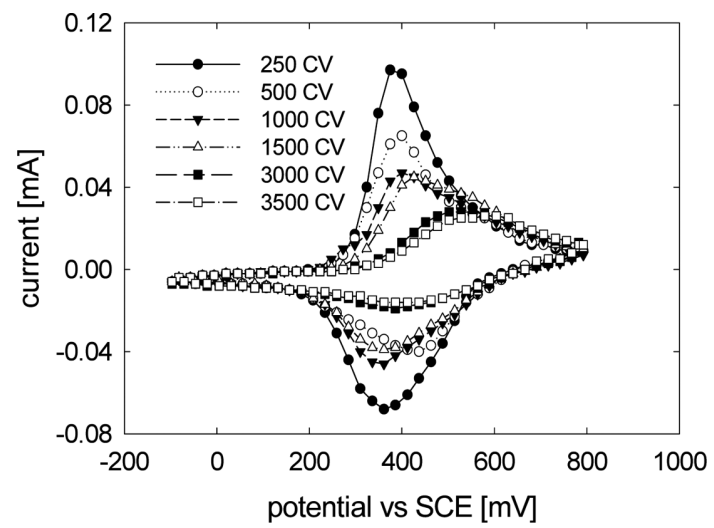

Fig. 3. Cyclic voltammograms of NiHCNFe in $1.0 \mathrm{M}$ $\mathrm{NaNO}_{3}$.

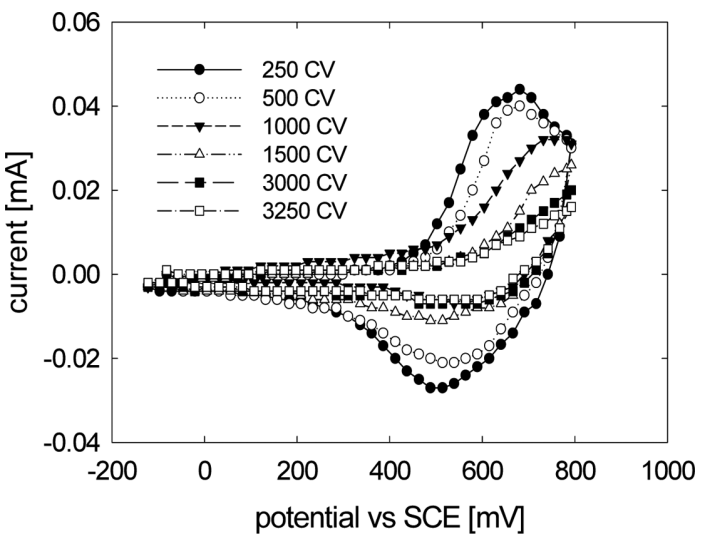

Fig. 4. Cyclic voltammograms of NiHCNFe in $1.0 \mathrm{M}$ $\mathrm{CsNO}_{3}$.

위나 전류 값을 결정할 수 있고, 다성분계 혼합물에서 전기화학적 이온교환 반응을 수행할 경우 어떠한 성 분이 선택적으로 처리되는지를 판별할 수 있을 것으 로 예상된다.

\section{2. $\mathrm{KNiFeCN}_{6}$ 이온교환체의 성능 감소율}

Fig. 3과 Fig. 4의 실험과 동일한 조건에서, 전위순 환 횟수와 $\mathrm{NiHCNFe}$ 이온교환 전극에 흐른 전기량과 의 관계를 조사한 결과가 Fig. 5와 Fig. 6이다. 두 실 험 결과에서 이온교환체로 흐른 전기량은 전위순환 횟 수가 반복될수록 감소하는 반비례 관계임을 알 수 있 는데, 이 결과는 양이온과의 산화-환원 반응을 반복할 수록 이온교환체의 반응 성능이 감쇄된다는 의미이다. 이온교환체와 나트륨간의 3,500회 산화-환원 반응에서 의 성능 감소율은 Fig. 5에서 약 $0.017 \% /$ cycle로 산 출되고, 이온교환체와 세슘간의 반응에서의 성능 감소 율은 Fig. 6에서 약 $0.019 \% /$ cycle로 산출된다. 또한 Fig. 5와 Fig. 6에서 초기 1,000회 동안의 성능 감소 율을 산출하면 각각 $0.045 \% / \mathrm{cycle}$ 과 $0.054 \% / \mathrm{cycle}$ 이 다. 이 결과는 코발트 수용액에서 측정한 이온교환체 의 성능 감소율이 $0.013 \% / \mathrm{cycle}$ 이었던 전보의 결과와 유사하고, ${ }^{21)}$ 또한 전기화학적 이온교환을 수행한 $\mathrm{HaO}$ 등6)이 순수 니켈에 $300 \mathrm{mV}$ 와 $700 \mathrm{mV}$ 를 300 초간 인 가하여 제조한 $\mathrm{NiHCNFe}$ 가 각각 $0.08 \% /$ cycle과 $0.02 \% / \mathrm{cycle}$ 로 측정되었다고 보고한 결과와 Chen 등 20)이 비전해법과 전해법으로 제조한 $\mathrm{NiHCNFe}$ 가 각각 $0.015 \sim 0.025 \% / \mathrm{cycle}$ 과 $0.065 \% / \mathrm{cycle}$ 의 성능 감소를 가진다고 보고한 결과와 거의 일치한다. 하지만 일반 이온교환법으로 실험을 수행한 Arm 등 ${ }^{10)}$ 의 보고에 의 하면 25 사이클 동안의 유기물 수지와 세슘의 이온교 환 과정에서 약 $60 \%$ 의 수지 부피가 감소하여 $2.4 \%$ / 


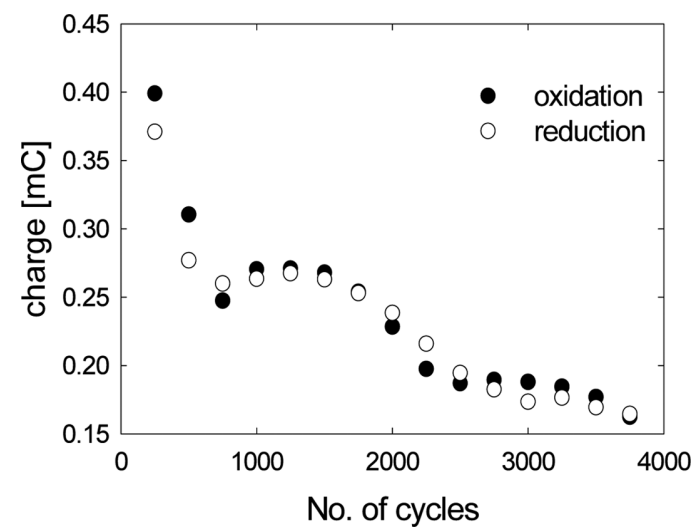

Fig. 5. Degradations of charge passing through oxidation and reduction with the number of cycles in $1.0 \mathrm{M} \mathrm{NaNO}_{3}$.

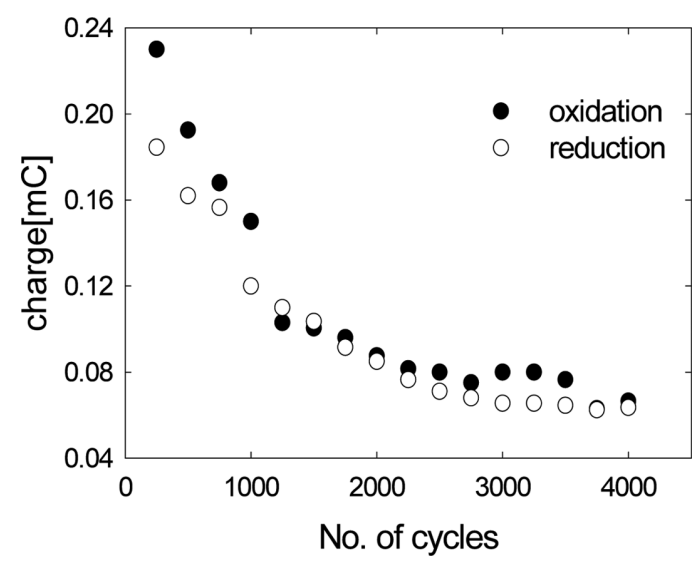

Fig. 6. Degradations of charge passing through oxidation and reduction with the number of cycles in $1.0 \mathrm{M} \mathrm{CsNO}$.

cycle의 성능감소를 가지며, Hassan과 Adu-Wusu' ${ }^{16)}$ 의 보고에 의하면 6 사이클 동안 세슘과의 이온교환 과 정에서 $\mathrm{RF}$ 수지는 약 $20 \%$ 의 성능을 잃어 $3.3 \% /$ cycle의 감소를 가진다. 두 경우에서 일반 유·무기물 이온교환체의 성능 감소율이 2 3\%/cycle로서 내구성 이 30 50회인 점과 비교하면, 전기화학적 이온교환체 인 $\mathrm{NiHCNFe}$ 의 성능과 내구성은 40 배 이상임을 알 수 있다. 따라서 전기화학적 이온교환법은 방사성 양 이온 성분의 분리 및 농축에 매우 효과적으로 그리고 경제적으로 활용될 수 있으리라 예상된다.

\section{3. $\mathrm{KNiFeCN}_{6}$ 이온교환체의 이온 선택성}

Fig. 7 은 세슘이 $20 \%$ 이고 나트륨이 $80 \%$ 인 이성분 계 혼합용액에서 측정한 순환전위곡선들이다. 이성분 계 용액에서의 산화-환원 피크 전류와 대응하는 전극 전위는 순수한 나트륨 수용액과 세슘 수용액에서 측

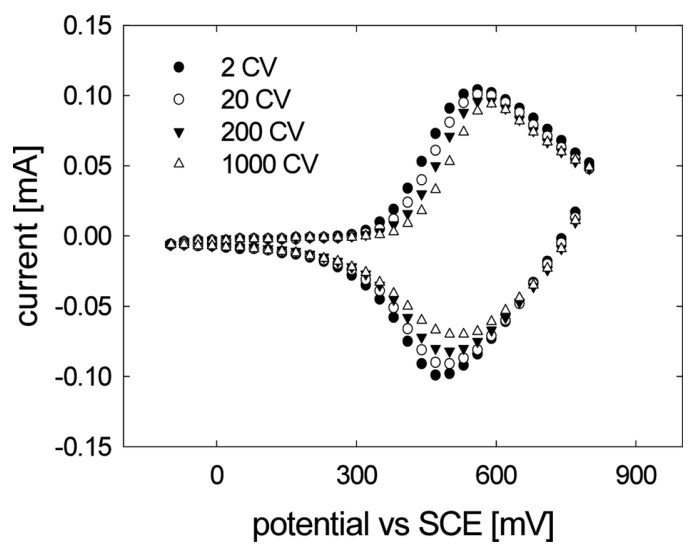

Fig. 7. Cyclic voltammograms in binary solution of $20 \%$ $\mathrm{CsNO}_{3}$ and $80 \% \mathrm{NaNO}_{3}$.

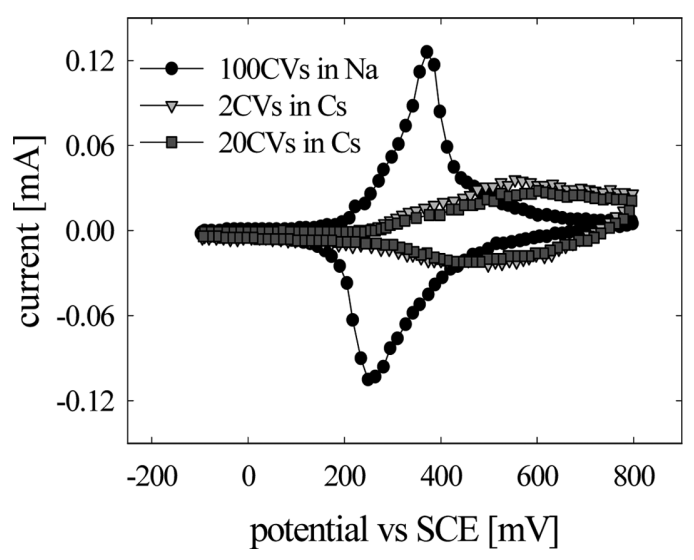

Fig. 8. Conversion of cyclic voltammogram due to the replacement of solution from sodium to cesium.

정한 값들의 평균값과 유사한 것으로 판단된다. 이 결 과는 $\mathrm{NiHCNFe}$ 이온교환체가 이성분계에서 두 성분 을 동시에 환원침적하고 산화해리한다는 의미이다.

나트륨과 세슘에 대한 이온 선택성을 확인하기 위해, 초기에 나트륨 수용액에서 100 회 동안 전위순환 한 $\mathrm{NiHCNFe}$ 전극을 세슘 수용액으로 이동시켜 20 회 동안의 전위순환을 추가적으로 실시해 보았다. Fig. 8 에 나타난 바와 같이, 세슘 수용액에서 단 2 회 정도만 전위순환하여도 순수한 나트륨 수용액에서 측정한 순 환전위곡선의 피크 전류와 대응하는 전극전위뿐만 아 니라 그 형태까지도 급격히 세슘 수용액에서의 특성 과 형태로 전환됨을 알 수 있다. 이 결과는 나트륨이 상당히 침적된 이온교환체라 하더라도 세슘 수용액으 로 교체하면 나트륨과의 반응은 정지되고 세슘과의 침 적-해리 반응이 신속히 이어진다는 의미로 해석된다. 
Fig. 8의 경우와 반대로, Fig. 9는 세슘 수용액에서 100 회 전위순환한 이온교환체를 나트륨 수용액으로 이 동시켜 20회 동안 전위순환한 결과로서, 나트륨 수용 액에서 2회 동안의 전위순환을 수행하여도 여전히 세 슘 수용액에서의 형태를 어느 정도 유지하고 있고 나 트륨 수용액 형태로의 전이가 상당히 느리다는 사실 을 알 수 있다. 다시 말해, Fig. 9의 2단계에서 사용 된 용액은 순수한 나트륨 수용액인데도 불구하고 세 슘과 나트륨이 동시에 산화-환원하는 거동을 나타낸 것이다. 이 현상은 먼저 이온교환체에 침적되어 있던 세슘이 산화과정에서 전극 표면으로 용해되고, 이어서 환원과정을 거쳐 전극과 용액 계면의 이중층에 있는 다량의 나트륨뿐만 아니라 미량의 세슘을 동시에 적 하하는 거동에 따른 결과라고 판단된다. 이상과 같은 Fig. 7 Fig. 9의 결과를 종합해 볼 때, $\mathrm{NiHCNFe}$ 이 온교환체의 이온 선택도는 나트륨보다 세슘에 대해 더 욱 높은 것으로 판단된다. Sinha 등 ${ }^{18)}$ 을 비롯한 다수 의 연구자들 ${ }^{7,23,25)}$ 의 발표에 의하면 이온교환 전극으로 의 산화-환원 퍼텐셜의 전달이나 전하전달 특성은 지 지전해질(폐수)내에 용해되어 있는 알칼리 금속 양이 온의 농도에 크게 의존하며, 양이온의 적하 및 해리는 용매전달을 수반한다고 보고하고 있다. 또한 양이온 선택성은 이온결합 원자직경이 클수록 우수하고, 이러 한 현상에 따라 세슘 $>$ 칼륨 > 나트륨 순으로 측정되 었다고 보고하고 있다. 이들 외에 $\mathrm{NiHCNFe}$ 를 사용한 $\mathrm{Li}$ 등 ${ }^{26)}$ 과 $\mathrm{RF}$ 수지를 사용한 Smith 등 ${ }^{27)}$ 의 보고에서 도 동일한 경향이 나타났다. 따라서 본 연구 결과는 타당한 것으로 판단된다.

기기분석을 통하여 $\mathrm{NiHCNFe}$ 이온교환체의 이온 선택성을 보다 정량적으로 검증하기 위해 Fig. 8에 해 당하는 실험을 수행하기 전과 후의 이온교환체를 단

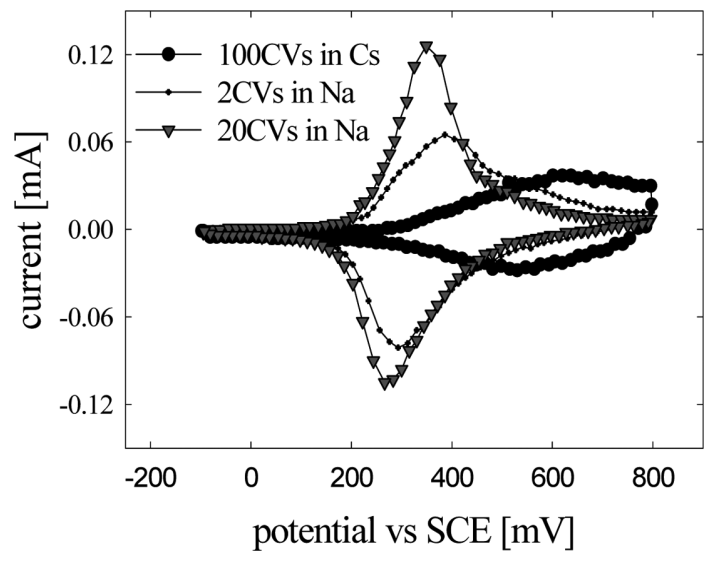

Fig. 9. Conversion of cyclic voltammogram due to the replacement of solution from cesium to sodium.

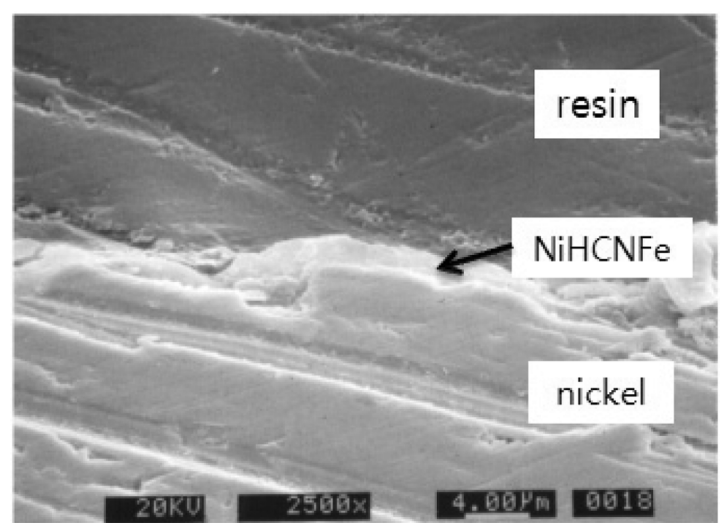

Fig. 10. SEM photograph of ion exchanger before experiment.

면으로 잘라 $\mathrm{SEM}$ 으로 촬영한 사진을 각각 Fig. 10 과 Fig. 11에 수록하였으며, 반응 후 이온교환체의 원 자조성을 EDS로 분석한 스펙트럼을 Fig. 12에 수록하 였다. 반응 전과 후의 사진을 비교하면 이온교환체의 두께가 반응 전 $2 \mu \mathrm{m}$ 에서 반응 후에 $5 \mu \mathrm{m}$ 이상으로 상당히 증가함과 동시에 밀착도와 조밀도가 다소 불량 한 형태의 막을 형성하였음을 관찰할 수 있다. Fig. 11 에서 관찰된 부드러운 막은 식(2)에서 기술한 바와 같 이 격자 빈 공간에 추가로 침적된 양이온들의 집합체 일 것이다. Fig. 10 에 나타난 반응 전 이온교환체의 원자조성은 $\mathrm{EDS}$ 분석에 의해 $\mathrm{K} 2.81 \%, \mathrm{Fe} 4.29 \%$, 그리고 $\mathrm{Ni} 92.91 \%$ 인 것으로 확인되었다. 이온교환체 의 원자조성은 $1: 1: 1$ 이지만 기지 금속이 니켈인 관계 로 니켈 함량이 매우 높게 측정된 것으로 판단된다. Fig. 11에 나타난 반응 후 이온교환체의 원자조성은

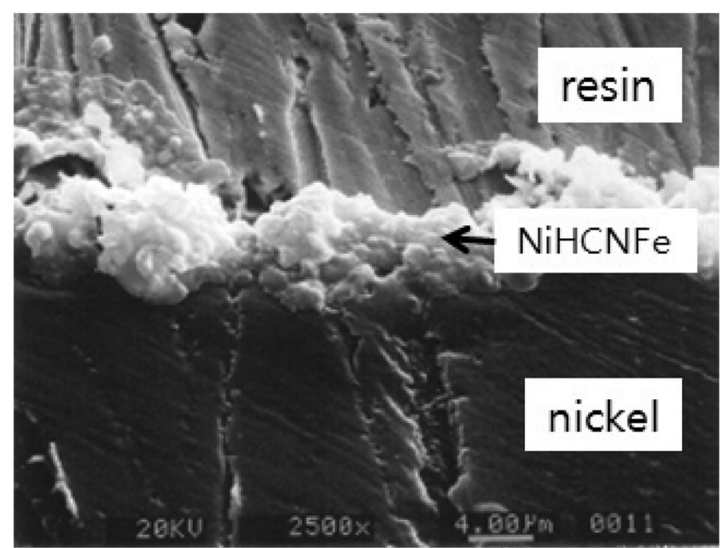

Fig. 11. SEM photograph of ion exchanger after the $100^{\text {th }}$ cycles in $1.0 \mathrm{M} \mathrm{NaNO}_{3}$ and the $20^{\text {th }}$ in $1.0 \mathrm{M} \mathrm{CsNO}$. 


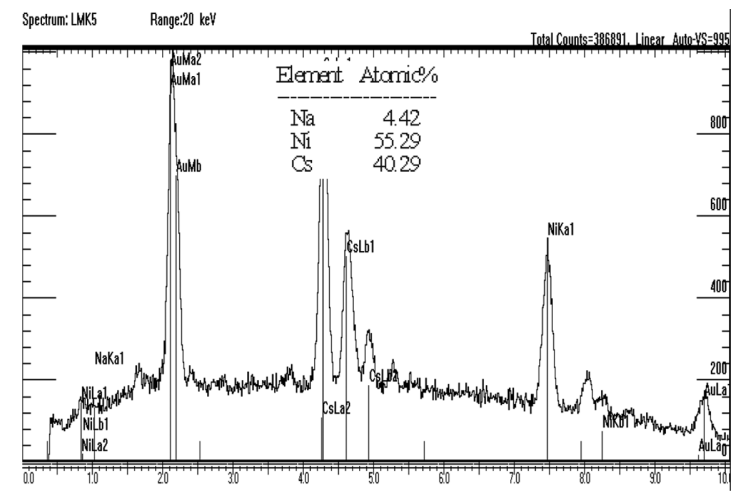

Fig. 12. EDS spectrum and atomic composition of ion exchanger after the $100^{\text {th }}$ cycles in $1.0 \mathrm{M} \mathrm{NaNO}$ and the $20^{\text {th }}$ in $1.0 \mathrm{M} \mathrm{CsNO}_{3}$.

$\mathrm{Na} 4.42 \%$, Cs $40.29 \%$, Ni $55.29 \%$ 로 분석되었다. 이 두 실험결과로부터 이온교환 반응 전과 후의 조성 은 분명히 다름을 알 수 있다. 또한 나트륨 수용액에 서 100 회 동안 전위순환하고 이어서 세슘 수용액에서 20 회 동안 전위순환하였지만, 이온교환체의 격자 중심 에는 나트륨보다 세슘이 훨씬 많이 침적되어 있음을 확인하였다. 세슘이 나트륨에 비해 약 10 배 정도로 많 은 조성임을 고려할 때, $\mathrm{NiHCNFe}$ 는 나트륨보다 세슘 에 대한 이온선택성이 월등히 높다고 간주할 수 있다.

\section{4. 결 론}

화학적 자생결합 반응으로 전기화학적 이온체인 $\mathrm{KNiFe}(\mathrm{CN})_{6}$ 를 제조하여 $1.0 \mathrm{M} \quad \mathrm{NaNO}_{3}$ 와 $1.0 \mathrm{M}$ $\mathrm{CsNO}_{3}$ 의 단일 및 이성분계 수용액에 시험전극으로 설 치하고, $\mathrm{SCE}$ 기준전극 대비 $-100 \mathrm{mV}$ 에서 $800 \mathrm{mV}$ 까지 전위를 연속적으로 순환하면서 시간, 전극전위, 전류, 전기량 등을 측정하여 순환전위곡선의 특성과 이온교환체의 성능 감소율을 조사하였다. 또한 두 용 액을 교차하여 이온교환 반응을 수행하고 반응 전과 후에 이온교환체의 형태 구조와 원자조성을 각각 $\mathrm{SEM}$ 과 EDS로 분석하여 이온교환체의 이온 선택성을 조사하였다. 본 연구 실험 범위에서 $\mathrm{KNiFe}(\mathrm{CN})_{6}$ 이온 교환체는 $1,000 \sim 4,000$ 회 동안 반복되는 산화-환원 반 응에서 안정적인 성능을 유지하였으며, 일반 유기물 이온교환체에 비해 약 40 배 이상의 우수한 성능과 내 구성을 가짐을 확인할 수 있었다. 또한 이온교환체는 이성분계 용액에서 나트륨 양이온보다 세슘 양이온과 보다 선택적으로 반응하는 특성을 가지므로, 혼합 용 액으로부터 세슘을 선택적으로 분리할 수 있다는 사 실을 알 수 있었다.

\section{감사의 글}

본 연구는 2012학년도 경남대학교 학술연구장려금 의 지원을 받아 수행되었으며, 이에 감사드립니다.

\section{참고문헌}

1. N. J. Bridger, C. P. Jones, and M. D. Neville, 'Electrochemical ion exchange' J. Chem. Technol. Biotechnol., 50, 469 (1991).

2. M. A. Lilga, R. J. Orth, J. P. H. Sukamto, S. D. Rassat, J. D. Genders, and R. Gopal, 'Cesium separation using electrically switched ion exchange' Sep. Purif. Technol., 24, 451 (2001).

3. C. A. Basha, P. K. Ghosh, and G. Gajalakshmi, 'Total dissolved solids removal by electrochemical ion exchange (IEX) process' Electrochim. Acta, 54, 474 (2008).

4. X. Hao, Y. Li, and M. Pritzer, 'Pulsed electrodeposition of nickel hexacyanoferrate film for electrochemically switched ion exchange' Sep. Purif. Technol., 63, 407 (2008).

5. H. C. Manosso and C. A. L. G de O. Forbicini, 'Treatment of wastes containing cesium ions by electrochemical ion-exchange (EIX)' J. Radioanal. Nucl. Chem., 279, 417 (2009).

6. X. Hao, T. Yan, Z. Wang, S. Liu, Z. Liang, Y. Shen, and M. Pritzker, 'Unipolar pulse electrodeposition of nickel hexacyanoferrate thin films with controllable structure on platinum substrates' Thin Solid Film, 520, 2438 (2012).

7. B. Sun, X. Hao, Z. Wang, and G. Guan, 'Continuous separation of cesium based on NiHCF/PTCF electrode by electrochemically switched ion exchange' J. Hazard. Mater, 233-234, 177 (2012).

8. E. H. Tusa, A. Paavola, R. Harjula, and J. Lehto, 'Industrial scale removal of cesium with hexacyanoferrate exchanger-Process realization and test run' Nucl. Technol., 107, 279 (1994).

9. D. E. Kurath, L. A. Bray, K. P. Brooks, G. N. Brown, S. A. Brayan, C. D. Carlson, K. J. Carson, J. R. DesChane, R. J. Elovich, and A. Y. Kim, 'Experimental data and analysis to support the design of an ion exchange process for the treatment of Hanford tank waste supernatant liquids', PNNL-10187, Pacific Northwest National Laboratory, Richland, Washington, USA (1994).

10. S. T. Arm, D. L. Blanchard, and S. K. Fiskum, 'Chemical degradation of an ion exchange resin processing salt solution' Sep. Purif. Technol., 43, 59 (2005).

11. D. Banerjee, M. A. Rao, and S. K. Samanta, 'Spherical resorcinol-formaldehyde performance testing with Hanford tank waste' Solvent Extra. Ion Exch., 26, 687 (2008).

12. T. P. Valsala, A. Joseph, J. G. Shah, K. Raj, and V. Venugopal, 'Synthesis and characterization of cobalt ferrocyanides loaded on organic anion exchanger' $J$. of Nucl. Mater, 384, 146 (2009).

13. M. R. Duignan and C. A. Nash, 'Removal of cesium 
from Savannah River site waste with spherical resorcinol formaldehyde ion exchange resin: experimental tests' Sep. Sci. Technol., 45, 1828 (2010).

14. D. Kolodynska, Z. Hubicki, and B. Kubica, 'Hexacyanoferrate composite sorbent in removal of anionic species from waters and waste waters' Sep. Sci. Technol., 47, 1361 (2012).

15. L. A. Bray, R. J. Elovich, and K. J. Carson, 'Cesium recovery using Savannah River Laboratory resorcinolformaldehyde ion exchange resin', $P N N L-7273$, Pacific Northwest National Laboratory, Richland, Washington, USA (1990).

16. N. M. Hassan and K. Adu-Wusu, 'Cesium removal from Hanford tank waste solution using resorcinol-formaldehyde resin' Solvent Extra. Ion Exch., 23, 375 (2005).

17. S. K. Fiskum, S. T. Arm, M. J. Steele, and M. R. Thorson, 'Spherical resorcinol-formaldehyde performance testing with Hanford tank waste' Solvent Extra. Ion Exch., 26, 435 (2008).

18. S. Sinha, B. D. Humphrey, and A. B. Bocarsly, 'Reaction of nickel electrode surface with anionic metal-cyanide complexes: Formation of precipitated surfaces' Inorg. Chem., 23, 203 (1984).

19. I. Carpani, M. Giorgetti, M. Berrettoni, P. Luigi Buldini, M. Gazzano, and D. Tonelli, 'A new approach for the synthesis of $\mathrm{K}^{+}$-free nickel hexacyanoferrate' J. Solid State Chem., 179, 3981 (2006).

20. W. Chen, J. Tang, H. Cheng, and X. Xia, 'A simple method for fabrication of sole composition nickel hexacyanoferrate modified electrode and its application' Talanta, 80, 539 (2009).
21. J. H. Lee and Y. G. Hwang, 'Preparation of nickel hexacyanoferrate ion exchanger for electrochemical separation of cations' Appl. Chem. Eng., 21, 52 (2010).

22. R. E. Sabzi, K. Kant, and D. Losic, 'Electrochemical synthesis of nickel hexacyanoferrate nanoarrays with dots, rods and nanotubes morphology using a porous alumina template' Electrochim. Acta, 55, 1829 (2010).

23. K. M. Jeerage and D. T. Schwartz, 'Characterization of cathodically deposited nickel hexacyanoferrate for electrochemically switched ion exchange' Sep. Sci. Technol., 35, 2375 (2000).

24. R. Chen, H. Tanaka, T. Kawamoto, M. Asai, C. Fukushima, M. Kurihara, M. Watanabe, M. Arisaka, and T. Nankawa, 'Preparation of a film of copper hexacyanoferrate nanoparticles for electrochemical removal of cesium from radioactive wastewater' Electrochem. Commun., 25, 23 (2012).

25. R. E. Gephart and R. E. Lundgren, 'Hanford tank clean up: A guide to understanding the technical issues', PNNL-10773, Pacific Northwest National Laboratory, Richland, Washington, USA (1995).

26. N. Li, Z. Li, J. Yuan, J. Hu, J. Miao, Q. Zhang, L. Niu, and J. Song, 'Nickel hexacyanoferrate nanoparticles anchored to multiwalled carbon nanotubes with a grafted poly(4-vinylpyridine) linker for electrically switched ion exchange' Electrochim. Acta, 72, 150 (2012).

27. F. G. Smith, L. L. Hamm, S. E. Aleman, and M. E. Johnson, 'Modeling ion-exchange for cesium removal from alkaline radioactive waste solutions' Sep. Sci. and Technol., 44, 2983 (2009). 